\title{
www.chuzetu.com as Social Media Facilitating Japanese Women's Abortion Experiences in The Context of Johoka Shakai
}

\author{
Diddah Annissaa'atul Shalihah ${ }^{1}$, Kurniawaty ${ }^{2}$ \\ \{diddah.ash@gmail.com ${ }^{1}$, daradwipa@yahoo.com ${ }^{2}$ \} \\ ${ }^{1,2}$ Universitas Indonesia, Depok, Indonesia
}

\begin{abstract}
This article discusses www.chuzetu.com as social media, which is a portal site for Japanese women aspiring to communicate their abortion experience with people having similar experiences, and other visitors aiming to have an abortion. This study uses qualitative methods, and the type of research is phenomenology. Using network society theory to focus on social movements by Manuell Castells, and Japanese Behavior theory by Takie Sugiyama Lebra to help explain the phenomenon of making www.chuzetu.com as an alternative media in communicating abortion experiences. In this study, three factors founded that encourage them to have an abortion, and they are (1) education, economics, psychology, (2) social considerations, (3) and health. Furthermore, media roles as a places for Japanese women to communicate their abortion experience are (1) to make social movements on the internet, (2) an alternative media in communicating abortion experience, (3) and to motivate Japanese women who had had an abortion. From these two findings, the phenomenon of making www.chuzetu.com as a place to communicate the experience of abortion is part of the \#MeToo campaign action.
\end{abstract}

Keywords: abortion experiences, Japanese women, media, social movements

\section{Introduction}

The advancement of media these days, compared to conventional media such as television, radio, newspapers, etc., the internet has four features. First, the internet can use letters, sounds, images, and videos on communication. The internet is not only a one-way information sharing media, but also it can be a medium for sharing information in two directions. Second, the internet can include all the content in television, newspapers, and magazines. Third, the internet has no boundaries on the territory, time, and circumstances. Fourth, the internet does not require much material in making its content. It means that newspapers, radio, and television require a lot of material in making content. In making a newspaper, an editor is needed to edit the collection of information before it is published, while television requires many people to create content [1].

It is interesting to note from those features, internet is an alternative medium for socializing in the community. Through the internet, people can socialize many things without worrying about any restrictions such as public media. That is reinforced by Furedi [2], who said that the internet and social media are powerful tools that can influence and shape people's behavior. Social media has also played an essential role in filing protests and social resistance today. The significant roles of social media led many observers to conclude that social media networks have the potential to promote public participation, involvement, and the process of 
democratization of public life. However, it is not the technological necessity itself that allows social media to play an essential role in social demonstrations. Instead, the creative use of social media is a response to pre-existing or at least independent aspirations and needs. This technology should be assumed as a resource that can be used by social and political movements seeking communication infrastructure to promote their struggles.

One example of using social media is campaigning \#MeToo. MeToo has been called for in many countries to encourage women to share their experiences of being sexually abused. By calling for this campaign, the wider community can realize the severe influence of sexual harassment on victims who have difficulty recounting their experiences. However, according to Smith [3], the \#MeToo campaign movement has not attracted much attention in Japan, but some Twitter users have shared their sexual harassment experiences. Castells [4] argues that it happens because those who have the same interests or feelings will get comfortable to share sadness and hope on the internet. From these similarities, those encourage them to connect, form networks on the internet, and support or help each other.

Besides \#MeToo, there are other things discussed in Japanese media, especially those relating to Japanese women. One of them is abortion by a Japanese woman. Based on the law, abortion is legal in Japan. However, the discussion of abortion in Japan is not yet open. According to Kakizaki [6], it is because abortion is a sensitive topic and sometimes difficult to discuss with friends and family. Indeed, some of them dare to tell their experiences in front of people, or some do not either. As an alternative, they chose to share their experiences on the internet for various reasons such as shame, fear of being fewer good women, and many others.

Japanese media rarely discussing abortion, thus bringing up other alternatives for obtaining information about abortion, such as how to have an abortion, getting or sharing experiences of having an abortion, and the risks involved in having an abortion. Moreover, to fulfil the needs of Japanese women to share their abortion experiences, there is a site called www.chuzetu.com. This site is an example of a portal that facilitates Japanese women in sharing abortion information and responding to other people's abortion experiences in their writing. Corresponding to the site header www.chuzetu.com, 中絶手術の不安を少しでも和げるた めに (chuuzetsu shujutsu no fuan o sukoshi demo yawarageru tame ni) [7] which in English means 'To ease the anxiety of abortion surgery', it has the primary mission to relieve the worry of Japanese women who have had an abortion. Information shared was in the form of a collection of experiences of Japanese women who had had an abortion. Through www.chuzetu.com, Japanese women who have had an abortion can communicate their personal experiences from first being aware of unwanted pregnancy, the dilemma of the choice of abortion or not, to the solution they are trying.

As the \#MeToo campaign on Japanese social media, there are also other issues raised. In Japan, there is a practice of abortion both among young women and women of childbearing age. According to Ohashi [8], based on medical abortion refers to the termination of pregnancy artificially. Through medical assistance, pregnancy can be stopped early in fetal development for a maximum of 22 weeks. While the social function, according to Yamamoto [9] abortion is to provide a solution for Japanese women seeking to abort an unwanted pregnancy. Their actions is legal if they still meet specific requirements that have been written in the Maternal Protection Law No. 156 article 14 of 1948 [10]. Based on that article, abortion in Japan is legal if there is an agreement from those requesting to have an abortion, and the abortion operation is carried out by individual doctors who have permission to practice abortion.

Through internet media, people can read information and contribute to sharing information without requiring a long time since it can be done by individual. The www.chuzetu.com sites is an example of a website that supports two functions; they are getting information about abortion 
and sharing the experience of having an abortion. This site facilitates Japanese women either who have never had an abortion will have an abortion, or who have had an abortion get and share information.

This study has two formulation of the problems, the background of the psycho-social and economic context that influence the decision to have an abortion, and the potential of www.chuzetu.com in accommodating Japanese women's social movements through its role as a media that facilitates sharing of abortion experiences.

\section{Methods}

This study uses qualitative methods, and the type of research is phenomenology. The data source of this study has been taken from the written record of the confession of Japanese women on the website www.chuzetu.com who had had an abortion. Existing data on the site is secondary data because the author does not act directly to search for the data. The number of data up to the end of 2018 is around 200 and continues to increase every time. The data chosen by the authors were taken from 2015-2018, which were selected based on the age of Japanese women having an abortion (15-25 years), and the typical experience written. From all these data restrictions, we took seven samples of data to be explained, those data are written by NN, Tears, $\mathrm{Zu}$, Chan, Paaman, Na, and Ya.

Table 1. Offenders Identity on www. chuzetu.com

\begin{tabular}{llc}
\hline Name & Data Date & The Age when the Offender has an Abortion \\
\hline NN & 2015.1 .13 & 22 years old \\
Tears & 2016.3 .6 & 19,20 years* \\
Zu & 2016.6 .5 & 3rd grade of Senior High School* \\
Chan & 2017.9 .16 & 25 years old \\
Paaman & 2017.9 .15 & 21 years old \\
$\mathrm{Na}$ & 2018.3 .19 & 14,15 years \\
Ya & 2018.5 .4 & 19 years old \\
\hline
\end{tabular}

* The offender does not explain the exact age when having an abortion.

Two concepts are used to explain seven datas. They are the concept of network society by Castells that focuses on social movements and Japanese behavior by Lebra that focuses on the relationship between status with shame, the dependence between mother and child, and Japanese anomic behaviour. However, before understanding social movements, Castells argues that there are three brief methodological statements needed to understand the analysis of social movements. Three methodologies in question are (1) they are what they say they are, (2) may be socially conservative, socially revolutionary, or both, or none, and (3) societal goal [11]. These three methodologies will become the general characteristics of every social movement.

Social movements throughout history are producers of new values and goals where the institutions of society are transformed to represent values by creating new norms to regulate social life. Social movements can train the strength of opponents by building themselves in the first position [12]. Characteristics of social movements based on Castell's theory [13] there are eleven. First, networked in multiple forms, movements are local and global at the same time, 
unlimited time, spontaneous in their origin, usually triggered by a spark of indignation, viral movements, leaderless movements, togetherness, highly self-reflective movements, non-violent movements, rarely programmatic movements, and aiming to change the values of society movements. Eleven of these features will be used to analyze the potential of the www.chuzetu.com site as a social media that facilitates the social movements of Japanese women in sharing abortion experiences.

The Japanese Behavior theory, based on Lebra, used the theories: the relationship between status with shame, the dependence between mother and child, and Japanese anomic behavior. These three theories are used to analyze the contents of articles written by seven selected Japanese women from the website www.chuzetu.com.

According to Lebra [14] for determining whether an action is real or not, Japanese people tend to think in dualism. According to the Japanese, good or bad is a relative problem, relative to social situations and impacts whose complexity can be beyond any judge's understanding. Like the remarks "Even a thief has a 30 percent truth". The Japanese also tend to hold all people involved in the conflict accountable. However, in resolving Japanese conflict lies in the consignment of what has happened to be forgot.

In a status, there is encouragement or demand for individuals to act according to their state. According to Lebra, the color, material, and style of a person's clothing must be by their age, gender, occupation, and so on. Lebra gave three examples from professors, children, and women. A university professor is expected to wear a black coat, white shirt, and tie. A child must behave like a child in general. While women must behave like women, and like bright colors [15].

However, if the appearance, behavior, or performance does not match the given status, it causes shame. Therefore, when someone is more aware of their position, then they are more easily embarrassed. Lebra argues that this is not to support Benedict's view of Japan, which has a stereotype of "diffident culture." Even so, Lebra agreed with Benedict that Japanese people are sensitive to shame, mainly because of their status orientation. Lebra argues that shame is relate to work status. [16]

The dependency accurately described by Lebra is the dependency relationship between mother and child. Four types of interdependence are interconnected to form culturally idealized relationships. First, the mother has power over the child. Second, the mother is the caregiver for the whole child from food, toilet, clothing, and health. Third, the desire to show satisfaction of the mother-child relationship. Finally, because the mother devotes her whole life to the welfare of her child, she becomes the person who is the most empathetic and sacrifice person where the child is helpless so that it depends on the mother [17].

Japanese anomic behavior refers to a normless state when there is no definite norm to control behavior. This normless situation usually occurs when someone goes abroad for the first time, goes to a new place for someone, and so on. When Japanese visit abroad, they tend to be in anomic condition. Conditions without these norms led to anomic actions in their ego. According to Lebra, anonymity is created not only in novel situations but in crowded conditions can also be created. Japanese people who are usually polite and organized, they can behave otherwise in a new place. One of the conditions exemplified by Lebra is the attitude of the Japanese when facing a full train at rush hour. The Japanese tend to think about their selfinterests in purpose to get into a crowded train. They do not hesitate to encourage others who are equally fighting over space on a crowded train. [18] 


\section{Results}

\subsection{Media Profile www.chuzetu.com}

\begin{tabular}{|c|c|c|}
\hline (i) www.chuzetu.com & $\cdots \vee$ Q & IIII \\
\hline 東京の中絶を中心とした病院の口コミ忡絶費用、そして中絶手術について & & ) \\
\hline
\end{tabular}

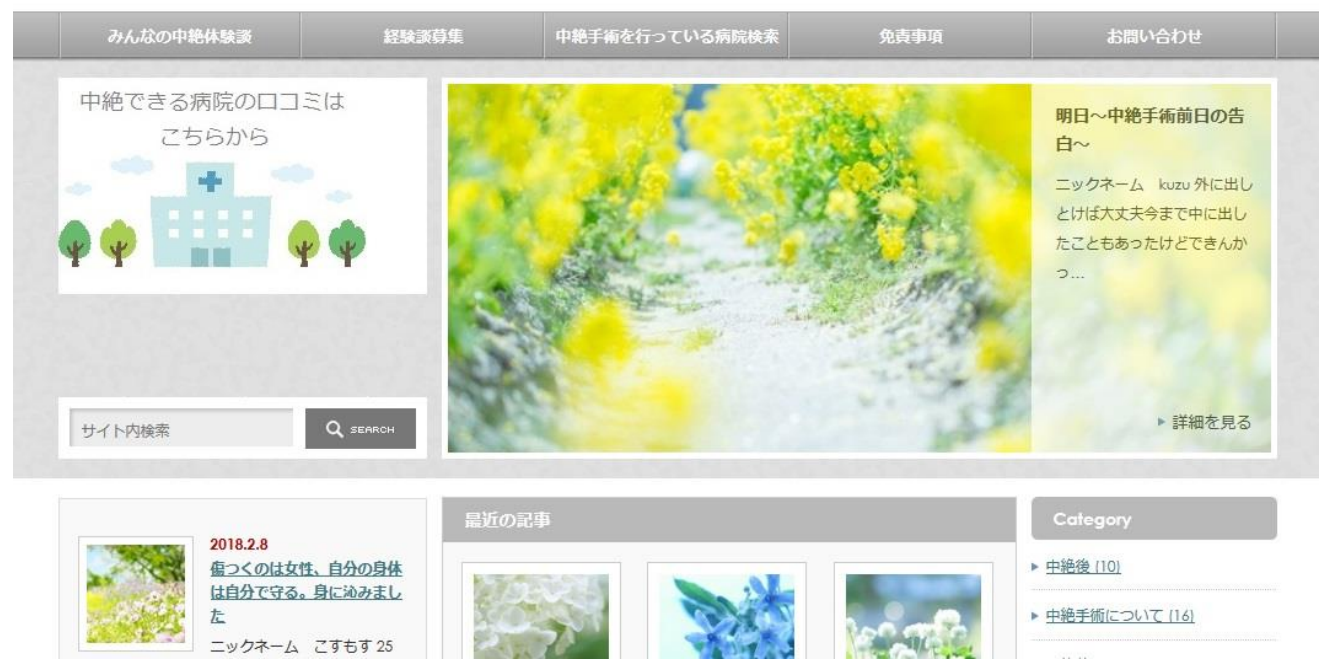

Fig 3.1 Screenshot of www.chuzetu.com

The website www.chuzetu.com is one of the communication media on the internet for some Japanese women who have had an abortion and who will have an abortion. On this site, there are more than 200 writings uploaded from 2011 to mid-2018. This site was first created in 2011 with the first writing discussing the reasons for women to have an abortion. The following year did not immediately receive a confession of writing women who had had an abortion, but the introduction to abortion starting from preparation, safe medical abortion techniques, the introduction of medical devices commonly used during abortion operations. It was only in 2014 that the site began actively receiving posts from several visitors who were Japanese women who had abortion experience and were looking for space to share their experiences. In the following years, this site remained active until mid-2018. However, in early 2019, this site could not be accessed by reasonable means. The site has stopped accepting posts again. However, even though it cannot be accessed, as usual, this site can still be accessed via archive web such as http://web.archive.org. The ease of access proves that social movements on the internet is not limited by time as they will always be stored and easily traced back.

The www.chuzetu.com site is an example of an internet-based social movement. Following the development of globalization and information, technology, and strength, social movement activities can change the human world. Those who are members of a social movement have the potential to move the community to revise or changing the social values that have long been held by the community. 


\subsection{The decision to have an abortion}

Japanese women who have had abortions are of various ages. Every year, the Japanese government releases abortion data. However, according to Sato et al. [19], the data does not explain the number of abortionists among unmarried and married women. Abortionists aged 1519 and 20-24 years have seen an increase. It is due to changes in sexual behavior among unmarried young women. They tend to engage in sex and have multiple sexual partners.

In this study, seven data has been taken from the website www.chuzetu.com. From the seven records, found three backgrounds of Japanese women decided to have an abortion, and they are (1) education, economic, and psychological, (2) social considerations, and (3) health aspects. These three backgrounds are made into one part because the three are interrelated. Education is the capital to get a better job and economy. Meanwhile, psychology is a condition when women are in conflict of mind and mind in deciding whether to abortion. If decisions are not carefully thought out, what they do will affect both education and the economy.

An example of a combination of educational, economic, and psychological backgrounds is in Paaman's writing [20] in the excerpt (i).

(i) 中絶をしたのは21歳、大学四年生の夏でした。

In the summer, when I attended my fourth year of college, I had an abortion at the age of 21

私は大学院を目指し試験も終え結果待ちの時期に彼氏と別れました。そして別れ はっか人

た後、自分が妊娠していることが発覚しました。コンドームで避妊していた事もあ

って驚きを隠せなかったのは事実です。

I planned to continue to master, and while waiting for the results of the exam, I broke up with my partner. After breaking up, I realized that I was pregnant. We once used condoms to prevent pregnancy and could not hide the shock.

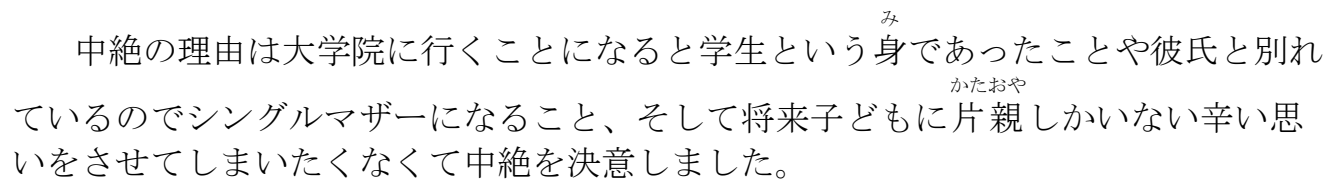

The reason I aborted pregnancy was to continue my master's degree. At that moment, because I had broken up with my partner, I would have been a single mother. Instead of making misery for the future of the child, I decided to abort it.

Paaman decided to have an abortion when he attended college in his fourth year. At that time, Paaman planned to continue her studies at the master's degree and was waiting for the results of the entrance examination. Paaman's relationship with her partner is over. However, after parting with a partner, Paaman realized that she was pregnant. Unwanted pregnancy was shocking for Paaman, especially she and her partner sure always use contraception every time they have sex.

Paaman's position at that time was disadvantaged. Paaman has planned her future by pursuing her educational career, which is to continue to the master's degree. On the other hand, Paaman must face the reality of unwanted pregnancy. After thinking through the solution 
carefully, Paaman chose to abort her pregnancy. Paaman also does not want to complicate her prospective children because later, she will be a single mother.

What happened to Paaman showed that her educational, economic, and psychological background influenced the decision to have an abortion. Paaman's plan to continue her education can be intended that there is something to be achieved for her future. With better education, one gets capital for a better economy. Besides education and economics, in the Paaman case, there is also a psychological background. Paaman thinks about the fate of her future child if she continues the pregnancy. Paaman did not want to give a wrong impression on her prospective child because she realized life as a single mother was heavy. Therefore, abortion is the best choice for Paaman.

Others around Japanese women on the www.chuzetu.com website also contributed to the decision to have an abortion. Their number and power are more than Japanese women as the case Ya [21].

(ii) 私は19歳で中絶手術をしました。

I had an abortion when I was 19 years old.

妊娠がわかった時は本当に頭が真つ白になりましたが、おろすことは全く考えて いませんでした。ですが彼が経済的な面やお互いの若さを考え、産むことに賛成を してくれませんでした。

When I found out I was pregnant, I did not know what to do, but I had never thought to abort the baby. However, my partner did not agree to continue the pregnancy because we were both economically incapable and still young.

でもそれでも私は諦めきれず彼を説得し産むことに決めました。ですがやはり親 が賛成をしてくれず、中絶を決めました。

Even so, I persuaded him so that I could still give birth. However, my parents did not allow me and were forced to decide on an abortion.

Based on the excerpt (ii), Ya seems still not understand what to bear if a woman is pregnant. Ya wants to continue the pregnancy and give birth to a child from a relationship with a partner. However, her partner refused because they were still not economically capable and were still young. Ya did not give up and continued to persuade her partner to support her giving birth to a child. Initially, indeed, her partner seemed to be supporting Ya. However, when dealing with parents, Ya is not permitted to continue the pregnancy. In the end, Ya decided to have an abortion.

From Ya case, it appears that she is still too young and does not understand her work as a mother if she continues her pregnancy. Her partner understood the risk if she continues her pregnancy, but from his actions, it seems that there is no accountability. However, coercion from her parents to abort the pregnancy proved that her parents did not want to let her future being ruined because of an unwanted pregnancy. A girl at her age should focus on education. Therefore, education is also an important asset before entering community life after starting work.

Furthermore, some still have to continue their academic careers, coercion from people around, and who have worked but are unable to economically and psychologically to take care of children, some are due to health aspects. Such conditions complicate their lives and are forced to choose an abortion to maintain their health. 
みはったつぎみ

(iii) 私が中絶手術をしたのは22歳のときでした。もともと子宮が未発達気味で、 せいりしゅうき

整理 周 期がおかしく、中学生のころからずっと婦人科の病院に通っていました。 みはったっす

そこでいつも言われていたのが、「子宮が未発達過ぎて妊娠できないだろう。自分

は子供が産めないと覚悟していてください」ということでした。

I aborted the pregnancy when I was 22 years old. At first, my menstrual cycle was irregular because the uterus had not yet developed, so I often went to the obstetric hospital since middle school. Therefore, I said it would be difficult to get pregnant and not be able to give birth.

ししゅんき

思 春 期にそんなことを言われ、やけくそのように避妊もせずにいたらまさかの妊娠 ひとまわ

でした。相手は付き合い始めて 2 年の一回り以上年上の彼氏です。

Knowing this fact, I had sexual relations without contraception until I had an unexpected pregnancy with a person I had dated two years who was 20 years older than me.

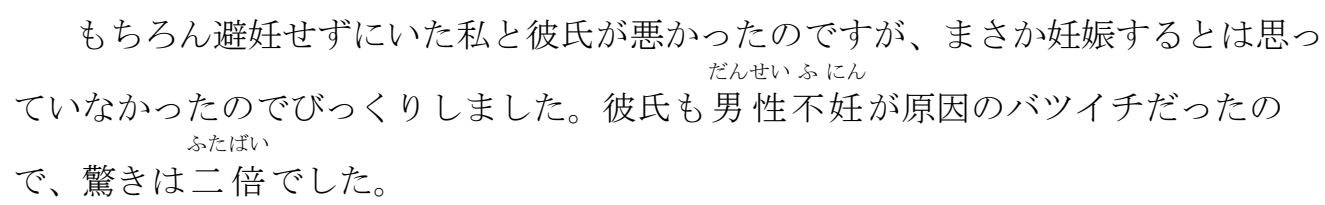

Indeed, not using contraception was my and my partner's mistake, but I was surprised to get pregnant. The shock doubled because my partner who had divorced because of infertility.

One example is writing from NN [22]. In excerpt (iii), NN first aborted her pregnancy at the age of 22 years, an age that was still in the safe range of pregnancy and childbirth. However, NN has had health problems since middle school. The uterus NN does not develop like women in general. Such conditions make NN regularly visit obstetricians. From the results of the checkup, NN was sentenced of not being able to get pregnant and give birth to a child. The decision to have an abortion is the right thing to do for NN.

Based on the three backgrounds that influence abortion decisions, Japanese women think in dualism. Following the implementation of the Lebra theory [14] in Japanese Behavior, Japanese women who share their abortion experiences at www.chuzetu.com are aware that their choice to have an abortion is wrong. They have killed a fetus resulting from sexual relations with a partner. However, their choices of having an abortion also has a truth that they can stand for.

Most of the background of Japanese women having an abortion is to protect themselves. That is under the opinion of Siller, Heidi \& Hochleitner [23]. Their actions are the embodiment of the slogan Mein Bauch gehort mir, which means that my uterus is mine. That is, women can decide for themselves to continue the pregnancy or choose to end the pregnancy. The notes of Japanese women on www.chuzetu.com are analyzed, there are objectives to protect themselves such as willing to continue their education, do not want to trouble the prospective children because they are not mentally and economically ready, do not want to worsen their health, and do not want to refuse orders from people who have power over them. If these women do not protect themselves, their ideas and hopes will be challenging to achieve.

In addition to feeling guilty, Japanese women also feel ashamed if they must tell their abortion experiences in public spaces using real identity. As already explained, in Japanese 
society, women who have had an abortion have a stigma, are considered unable to carry out the role of motherhood and considered to have bad maternal signs. The three wrong assumptions were not following the community, and in the end, they did not dare to tell their abortion experiences.

According to Lebra, appearance, behavior, or performance that is not under the status given will cause embarrassment. Therefore, if someone is more aware of the status, then she/he is more easily embarrassed. Lebra believes that this is not to support Benedict's view of Japan, which has a stereotype of "diffident culture". Even so, Lebra agreed with Benedict that Japanese people are sensitive to shame, mainly because of their status orientation. Lebra argues that shame is related to work status [16]. Therefore, Japanese women who have had an abortion are usually aware of their employment status. For those who are still students, they try to act like students in general. For example, prioritizing education rather than continuing her pregnancy.

Based on the shame culture described by Lebra [24], status is usually associated with shame when two conditions are filled. On the website www.chuzetu.com, Japanese women who have had abortions consist of various kinds of status. Japanese women who are still students should prioritize education. If they choose another path, such as being pregnant and having to take care of a child, that is not something the student does. Mismatched age and status will make them ashamed.

However, at certain time they can be honest, for example, on the internet. On the internet, they can use anonymous identities to tell of unwanted pregnancy experiences, abortions, and problems after an abortion. They can be honest and express their honne (real intention) on the internet because there is no worry of being exposed due to anonymous identities. Therefore, they are free to show anomic behavior. It is consistent with the concept of Japanese anomic behavior described by Lebra. If related to this research, the site www.chuzetu.com is a new place in the middle of the internet.

In some writings, especially teenagers who experience unexpected pregnancies, there is control from other parties around them. One of them, $\mathrm{Na}$ [25] was ordered by her mother to abort her pregnancy. Na's mother's position is higher than Na's child status, so she has more power and can force $\mathrm{Na}$ to abort a pregnancy. It is following the concept of dependency between mother and children as described by Lebra. Behind the forced abortion, Na's mother put hope in $\mathrm{Na}$ to obey her as a form of reciprocation that is not free. Because as we well know, a mother who sacrifices her life to take care of a child starts from eating, toilet, clothes, and health.

(iv) 中2（14歳）6月、中3（15歳）12月に2度も中絶手術を行いました。

I had an abortion twice during the 2 nd grade of middle school (14 years) in June and the third grade of middle school (15 years) in December.

中1の頃からずっとお付き合いしていた彼がいました。彼は普通に中出ししてい ました。私は経験がなく無知だったため、中に出されていることに気付きませんで した。

I have been dating a boy since grade 1 junior high school. He usually penetrates sperm inside. I was unconscious because I did not know and was inexperienced.

しかし、生理がこなくなり、吐き気がする日々が数ヶ月続きました。私は自分で 検査薬を買いに行きました。妊娠していました。その後も親に言うことができずに 数ケ月経ちました。 
However, I am late for menstruation and feel the days of nausea. I bought a pregnancy test myself. The result is pregnant. After that, I could not tell my parents for several months.

私は自殺をするつもりでいました。その時自殺していればよかったのに、結局死
ぬ勇気は出ませんでした。
I meant to kill myself. Although at that time, it was better to kill myself, in the end, I did not dare to die.

さすがに母親が気づいて、病院へ行き、中期中絶しました。役所に届けを出し、 火葬をしました。親には、彼と今後一切関わるなと言われたので、その時の通院か ら手術、火葬まですべて私と両親だけで行いました。

My mother noticed something different about me, took me to the hospital, then ordered an abortion.

Therefore, my parents told me not to see my boyfriend again.

$\mathrm{Na}$ has tried to keep her pregnancy a secret from her partner and parents. The intention of suicide ever thought of, but Na did not dare to commit suicide. Only after the mother realized there was something strange about Na's health condition, $\mathrm{Na}$ was told to go to the hospital, then after the checkup showed positive pregnancy, her mother immediately told $\mathrm{Na}$ to abort the pregnancy quickly. After dealing with the hospital, Na was forbidden to see her partner again.

If analyzed from excerption (iv), women of the same age as $\mathrm{Na}$ are very young because they are still in puberty. Continuing pregnancy will have a high risk for Na's body. Supposedly, women at the age of focus on junior secondary education where biology is usually about reproduction begin to introduce.

\subsection{Potential role of the Media www.chuzetu.com As a Container for Japanese Women's Social Movements}

The experiences of Japanese women who have abortions at www.chuzetu.com were researched to find the potential of the site. Following the theory of Castells [26], the actions of Japanese women produce real virtue. They do not directly communicate with each other, but if analyzed in various writings, there are responses aimed at readers and people who have written before. It shows the potential of the site $\underline{w w w . c h u z e t u . c o m}$ as social media.

In other words, the website www.chuzetu.com acts as an alternative media that facilitates abortionists in Japan. The embodiment of an internet-based social movement for Japanese women who shared their abortion experiences on www.chuzetu.com formed a space that became their new place. This space is used by them to create a community based on togetherness because the places that exist and have been occupied no longer mean anything to them, and this space is also evidence of their social movements.

Following the theory of Castells [27] Japanese women who share their abortion experiences on the website www.chuzetu.com have a sense of togetherness with other Japanese women who share their abortion experiences as well. The similarity of experiences, feelings of anxiety, regret, and feelings of seeking to be heard, brought them to the site. From the sense of togetherness that exists, they motivate each other through writing. 
(i) 不安でいっぱいで、つらい時があります。この気持ちは一生背負って生きなけ ればならないと思います。同じ思いを抱えている方がいるということをこのサイト で知ったので、少し頑張れる気がしています。

I was anxious, and I had a hard time. I think this feeling will be carried out for a lifetime. But because I know that there are people on this site who feel the same way, I feel a little happy.

(Na, 2018.3.19)

An example is a excerpt (i) from $\mathrm{Na}$ [25]. At first, $\mathrm{Na}$ thought his anxiety would be carried out for a lifetime. However, after finding this site, Na began to feel a little excited because she was not the only one who felt the same problem.

Although the experience of abortion can be shared through www.chuzetu.com, the writings of Japanese women are not as massive as the writings of Alyssa Milano on Twitter and other women in the world who share their experiences of sexual abuse. The reason for the difficulty of recognizing viral Japanese women who have abortions is because of the way they convey their experiences. Japanese women tend to use anonymous identities when sharing their experiences. According to Hasunuma and Shin [28], this was expected because they considered the risk of telling their experiences. If they share their experiences in public using their real identities, it can affect their careers in the workforce, and can even influence the careers of sexual harassers as well. Therefore, abortion recognition writings are difficult to viral.

The writings on the www.chuzetu.com website have implied intent. In some of their confessions, they felt they could not find the right space to tell their experiences. Only on this site, they can tell all experiences of abortion until after abortion. Some of them do not want to complicate the people around them if they complain a lot. The selection of this site as a place to share also shows that there are no mainstream media that can accommodate them. The act of sharing abortion experiences on this site can aim to change feelings and spark debate, but there is no intention to create a group in public. They want to be listened in a room that can accept the abortion experience.

(ii) 長々と、中絶以外の事も交えての長文、大変申し訳ございません。 誰にも話せない気持ちをここで書き込みました。ありがとうございました。

I am very sorry, and I am sorry for the extended writing about abortion.

I am writing here because this feeling cannot be talked with anyone. Thank you very much.

One example is the experience of Tears [29]. In excerpt (ii), she writes her experience on the site because her abortion experience cannot be told to anyone, not even to friends and family. Writing down her experience on the sites is the best choice for her.

According to Kodama [30], the mass media has great potential as a catalyst for revolution, dispels prejudices and ideas, and expands women's attitudes towards society. The media is also said to have a positive effect on strengthening recognition of the growing role and promoting women's participation in the development process. At the same time, the action plan shows that there are problems with women's participation in media and media content. The internet is also a media. Women's contribution to the website www.chuzetu.com can be a useful start to the role of women in the media in the future.

The site www.chuzetu.com has an alternative media role in communicating the abortion experience shared by Japanese women through writing uploaded on the site. The significant role of www.chuzetu.com as an alternative media to communicate abortion proves that the internet has the potential to be a community mobilizer. That is under what Kodama [31] said, the media 
can be a force to develop society. Furthermore, the media can also be a social tool that can maintain and strengthen old awareness.

The role of other media can be a motivator for certain communities. As is well known, the benefits of the media today are not only as a medium for obtaining information and sharing information but are growing year by year. It means that using the media as a place that can motivate is new.

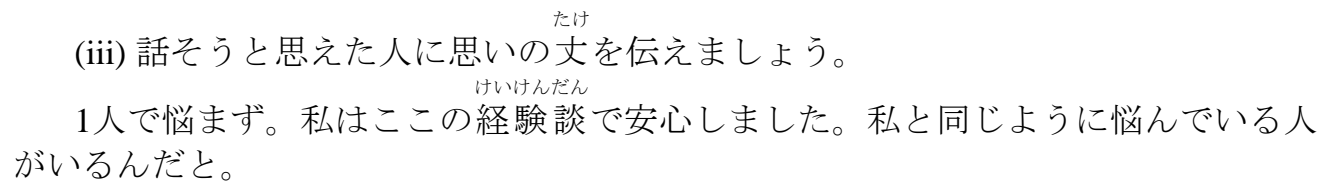

Let us say it to people who are thinking of telling stories.

There is no need to save the story yourself. I feel calm because there is a place to share this experience. I realized that some people experienced the same thing.

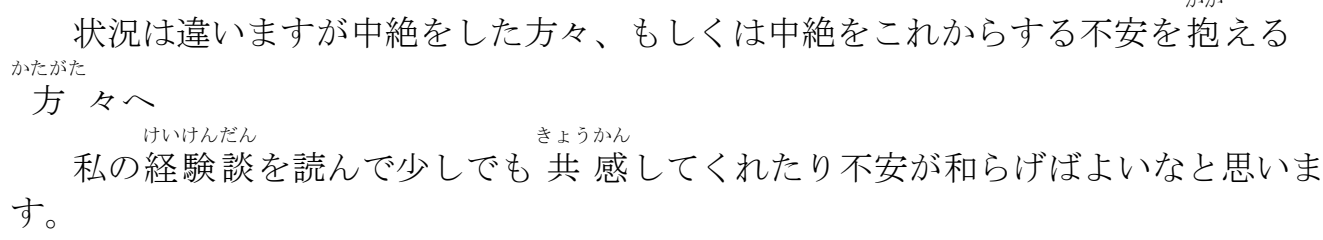

Even though the situation is different, but I want to say something to people who abort the pregnancy, or people who are confused will abort pregnancy.

Reading experience, I can reduce the displeasure because we feel the same way.

Paaman [20] in excerption (iii) invites people to share their abortion experiences with the hope of easing the burden that has perceived. However, unlike women who have shared their experience on the site, Paaman also advised that getting support from parents, friends, and partners is very important.

From all analyzes of data based on Network Society theory by Castells, it can be found that the main background makes www.chuzetu.com play a role in facilitating abortion in Japan. The embodiment of an internet-based social movement for Japanese women who shared their abortion experiences on www.chuzetu.com and formed a space that became their new place. This space is used by them to create a community based on togetherness because the place that exist and have been occupied no longer mean anything to them, and this space is also evidence of their social movements.

Like Ozawa's [32] research on the phenomenon of suicide on the internet, the authors argue that the phenomenon of communicating the experience of abortion on www.chuzetu.com also illustrates the strong need to affiliate with others. By sharing abortion experiences and reflecting on other people's abortion experiences, they will feel sentiments with others who have the same fate. If an internet-based community was created in a structured manner and its members are active, in the future other spaces will develop in public.

On the other hand, the emergence of social movements on the internet can be evidence of the weakening of the role of family institutions in Japanese society. Family institutions should be the leading institutions that fully help members who are experiencing problems, especially women who have had an abortion. However, for people in Japan where marriage rates are declining, it is challenging to realize the ideal role of family institutions. 


\section{Conclusion}

After researching the media www.chuzetu.com, found three profiles of Japanese women who communicate their abortion experiences at www.chuzetu.com. The three profiles are as follows:

1. Woman who not having the opportunity to share their abortion experiences in public spaces. It is due to the consideration of women's status, lousy stigma, and the surrounding environment that is not supportive. By using another identity or anonymous, they can tell stories without having to bear the shame.

2. Woman who need a place consisting of people who can accept their abortion experiences. Choosing to communicate it on www.chuzetu.com can create a sense of community with others who have the same experience. Although what they did on the site did not become viral on the internet, the actions they took were still part of the women's social movement, the \#MeToo campaign.

3. Woman who seek psychological motivation from other. Because the family institution did not work as it should, the media www.chuzetu.com came and replaced the role of the family institution.

Moreover, the role of the www.chuzetu.com media in facilitating abortionists in Japan through sharing abortion experiences raises three potentials that will occur in the future. The three potentials are as follows:

1. A subtitute for a family institution is not working as it should. The family institution described in some abortion records could not help the Japanese women. Although the problem of an unwanted pregnancy can be solved by abortion, other problem such as psychological will overshadow the women. That is because abortion is a lasting experience for women. Women cannot solve the problem of abortion alone. Assistance from people around women is needed because outside support is an essential element that can organize their lives after having an abortion.

2. Develope enthusiasm and strength to Japanese women, so that it can inspire other Japanese women to raise other sensitive themes on the internet.

3. If social movements on the internet run in a structured, organized manner and many members are active, there is potential for public space for emerging in future social movements. As more and more women with the same interests are brought together on the internet, and routinely interact, the sentiment between them will be strong and bring up their potential desire to show themselves in public.

At present, only on the internet they show contributions to their groups. Starting from the internet, the government should bring up programs that can alleviate their problems. For example, the government provides media-related policies for these women and controls other social institutions in the real world if family institutions are difficult to evaluate. Meanwhile, an institution can invite women through the internet, then hold regular meetings in the public space to communicate the problem and find solutions to the problems together.

\section{Acknowledgements}

I thank to my supervisor, Ms. Kurniawaty for guiding this research. She has given suggestions, ideas, and input in this research. Then, we also thank the committee of 3rd ICSGS 2019 for providing the opportunity to present, and publish this research. This research is part of my postgraduate thesis under the guidance of Ms. Kurniawaty. 


\section{References}

[1] Hashimoto, Y. 『ネットワーク社会』in メディア学の現在〔新訂第 2版〕.Japan: Sekaishishosha. pp. 139-142 (2015)

[2] Furedi, Frank. How the Internet and social media are changing culture. http://www.frankfuredi.com/article/how_the_internet_and_social_media_are_changing_culture 1 .

(2015) Retrieved on 4 March 2018.

[3] Smith, Alyssa I. \#MeToo assault campaign hits Japan. https://www.japantimes.co.jp/news/2017/10/21/national/media-national/metoo-assault-campaign-hitsjapan/. (2017) Retrieved on 20 September 2018

[4] Castells, M. Networks of outrage and hope: Social movements in the Internet age. USA: John Wiley \& Sons. pp. 1 (2015)

[6] Kakizaki, Su. Abortion in Japan - What you need to know. https://healthytokyo.com/blog/abortionin-japan-what-you-need-to-know/. (2015) Retrieved on 5 March 2018.

[7] 中絶手術の不安を少しでも和らげるためにhttp://www.chuzetu.com/ Retrieved on 27 February 2018

[8] Ohashi, Yukako. Eugenic Laws and the Criminalization of Abortion in Japan. http://web.icu.ac.jp/cgs_e/2015/09/n1018-06.html. (2015) Retrieved on 4 March 2018.

[9] Yamamoto,M..『望んだ妊娠から消される子ども一中期中絶から死産児へ』in 女性学研 究. Osaka: Osaka Prefecture University. pp 26 (2016)

[10] Maternal Health Act.

http://www.japaneselawtranslation.go.jp/law/detail/?id=2603\&vm=04\&re=02. Retrieved on 11 December 2017

[11] Castells, M. The power of identity: Second edition with new preface. USA: Blackwell Publishing. pp. 73-74 (2010a)

[12] Castells, M. Networks of outrage and hope: Social movements in the Internet age. USA: John Wiley \& Sons. pp. 9 (2015)

[13] Castells, M. Networks of outrage and hope: Social movements in the Internet age. USA: John Wiley \& Sons. pp 221-228 (2015)

[14] Lebra, T. S.,. Japanese patterns of behavior. USA: University of Hawai'i Press. pp. 11 (1976)

[15] Lebra, T. S.,. Japanese patterns of behavior. USA: University of Hawai'i Press. pp. 78-79 (1976)

[16] Lebra, T. S.,. Japanese patterns of behavior. USA: University of Hawai'i Press. pp. 79 (1976)

[17] Lebra, T. S.,. Japanese patterns of behavior. USA: University of Hawai'i Press. (1976) 57-58

[18] Lebra, T. S.,. Japanese patterns of behavior. USA: University of Hawai'i Press. (1976) 131-132

[19] Sato, R., Shiraishi Noriko, Bando Rieko. Induced abortion in Japan --- A demographic analysis of its trends and causes --- Tokyo: National Institute of Population and Social Security Research. pp. $15(2008)$

[20] Paaman. Shujutsugo no watashi.

http://www.chuzetu.com/?p=1000003424. (2017) Retrieved on 27 February 2018.

[21] Ya. Kono kimochi o hakidasu ba ga koko shika naku, kakasete itadakimashita. http://www.chuzetu.com/?p=1000003580 (2018) Retrieved on 1 July 2018

[22] NN. Shishunki ni ninshin dekinaidarou to ishi kara iware, yake ni natte shimatta kekka ninshin shita josei no chūzetsu taiken $\mathrm{http} / / / \mathrm{www} . c h u z e t u . c o m / ? \mathrm{p}=107$. (2015) Retrieved on 28 February 2018. [23] Siller, H. \& Hochleitner, M.. Abortion as one aspect of Women's Health in HEALTH CARE FOR WOMEN INTERNATIONAL VOL. 38, NO. 9, 907-912. Taylor \& Francis. pp. 907 (2017)

[24] Lebra, T. S.. Japanese patterns of behavior. USA: University of Hawai'i Press. pp. 80 (1976)

[25] Na. Gakusei de nikai chüzetsu, gomennasai.

http://www.chuzetu.com/?p=1000003560. (2018) Retrieved on 1 July 2018.

[26] Castells, M.. The rise of the network society, second edition. USA: Blackwell Publishing. pp. 404$405(2010 b)$

[27] Castells, M. Networks of outrage and hope: Social movements in the Internet age. USA: John Wiley \& Sons. (2015) 
[28] Hasunuma, L. \& Shin, Ki-young. \#MeToo in Japan and South Korea: \#WeToo, \#WithYou in Journal of Women, Politics \& Policy VOL. 40, NO. 1, 97-111. Routledge. (2019)

[29] Tears. Yon dome no chüzetsu o oete http://www.chuzetu.com/?p=1000001527. (2016) Retrieved on 28 February 2018.

[30] Kodama， M. メディアとジェンダー in メディア学の現在〔新訂第 2版〕.Japan: Sekaishishosha. pp. 227-228 (2015)

[31] Kodama， M. メディアとジェンダー in メディア学の現在〔新訂第 2版〕.Japan: Sekaishishosha. pp. 226 (2015)

[32] Ozawa-de Silva, Chikako. Shared Death: Self, Sociality and Internet Group Suicide in Japan in Transcultural Psychiatry Vol 47(3): 392-418. Sagepub. (2010) 